\title{
Massive Envenomation by Bees Sting in a Child in Togo
}

\section{Djatougbe Ayaovi Elie Akolly*, Koffi Mawuse Guedenon, Enyonam Tsolenyanu, Lidi Kama Bessi, Didier Koffi Gnamey, Yao Atakouma}

Chu Sylvanus Olympio, Lome, Tago

Email: *elianeakolly@yahoo.fr

How to cite this paper: Akolly, D.A.E., Guedenon, K.M., Tsolenyanu, E., Bessi, L.K., Gnamey, D.K. and Atakouma, Y. (2016) Massive Envenomation by Bees Sting in a Child in Togo. Open Journal of Pediatrics, 6, 232 236.

http://dx.doi.org/10.4236/ojped.2016.63032

Received: July 25, 2016

Accepted: September 3, 2016

Published: September 6, 2016

Copyright $\odot 2016$ by authors and Scientific Research Publishing Inc. This work is licensed under the Creative Commons Attribution International License (CC BY 4.0).

http://creativecommons.org/licenses/by/4.0/

\begin{abstract}
Attacks by swarm of bees realize arrays of mass poisoning. We report the case of a 9 years old boy whoes severity was related to the large number of bees which was about 400 and their locations spread throughout the skin surface with a preponderance to the cephalic end. Complications were hemolytic anemia, kidney failure and convulsions. The outcome was favorable with symptomatic care and hemodialysis.
\end{abstract}

\section{Keywords}

Bee, Envenomation, Renal Failure, Child, Togo

\section{Introduction}

African's bees are very aggressive and their attacks are very often massive [1] [2]. The intensity of the envenomation and the prognosis are directly related to the number of stings. Thus, 250 to 500 stings can cause the death of an adult man [3]. Simple stings are responsible for a local reaction with hives even sometimes with anaphylaxis and multiple stings cause a toxic syndrome with systemic symptoms [4]. We report the case of 9 years old boy who survived after a massive envenomation complicated of renal failure.

\section{Observation}

It is the case of 9 years old boy with no notable medical history, admitted an hour after an attack by a swarm of bees during mangoes gathering. The stings were focused on the cephalic end, all the four legs and the chest (Figure 1 and Figure 2). The examination revealed a conscious child, very painful, agitated, with swelling of the face causing complete lid closure, erythematous pimples centered by stings at almost all the skin 


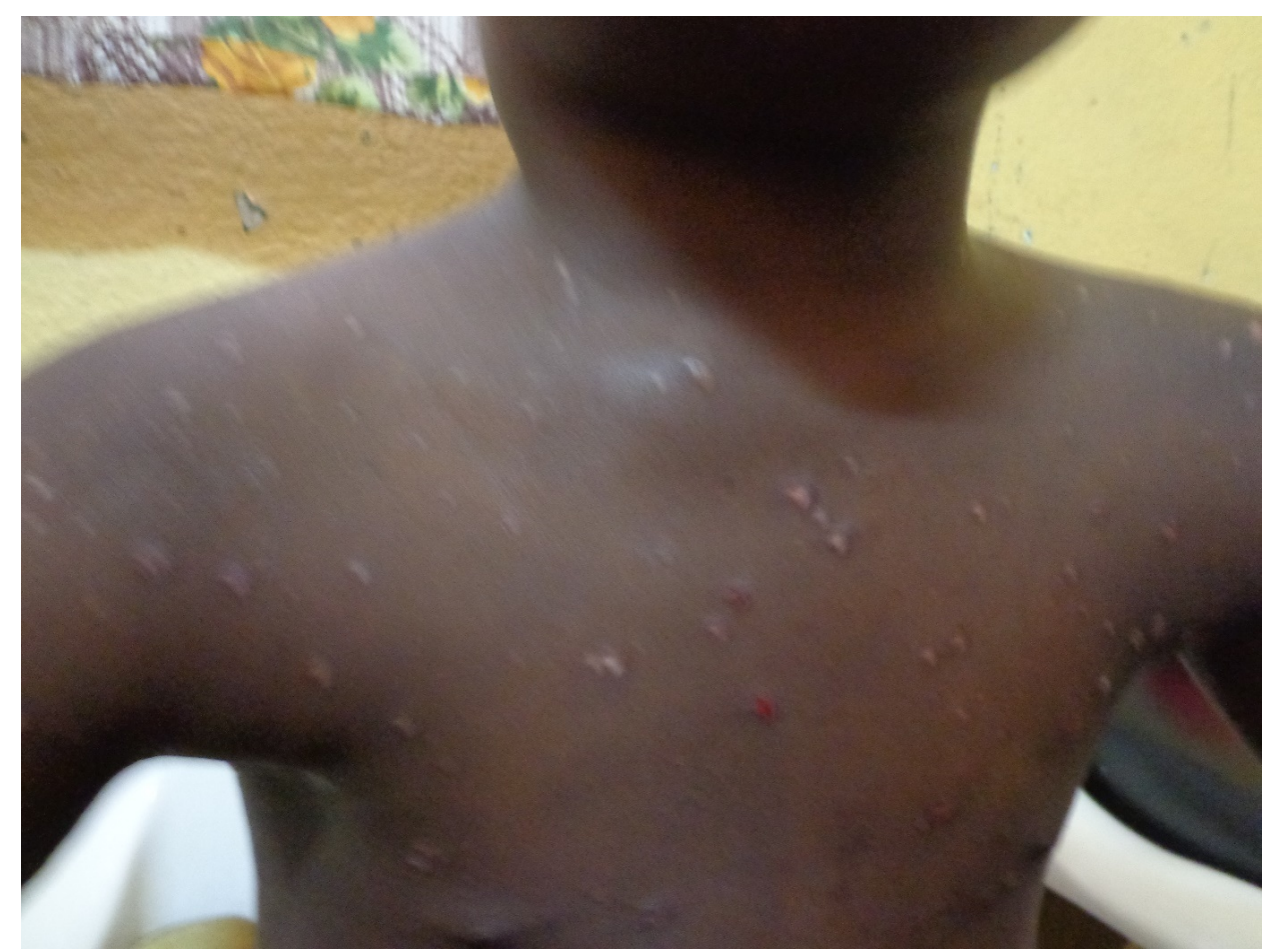

Figure 1. Thoracic location of bee stings.

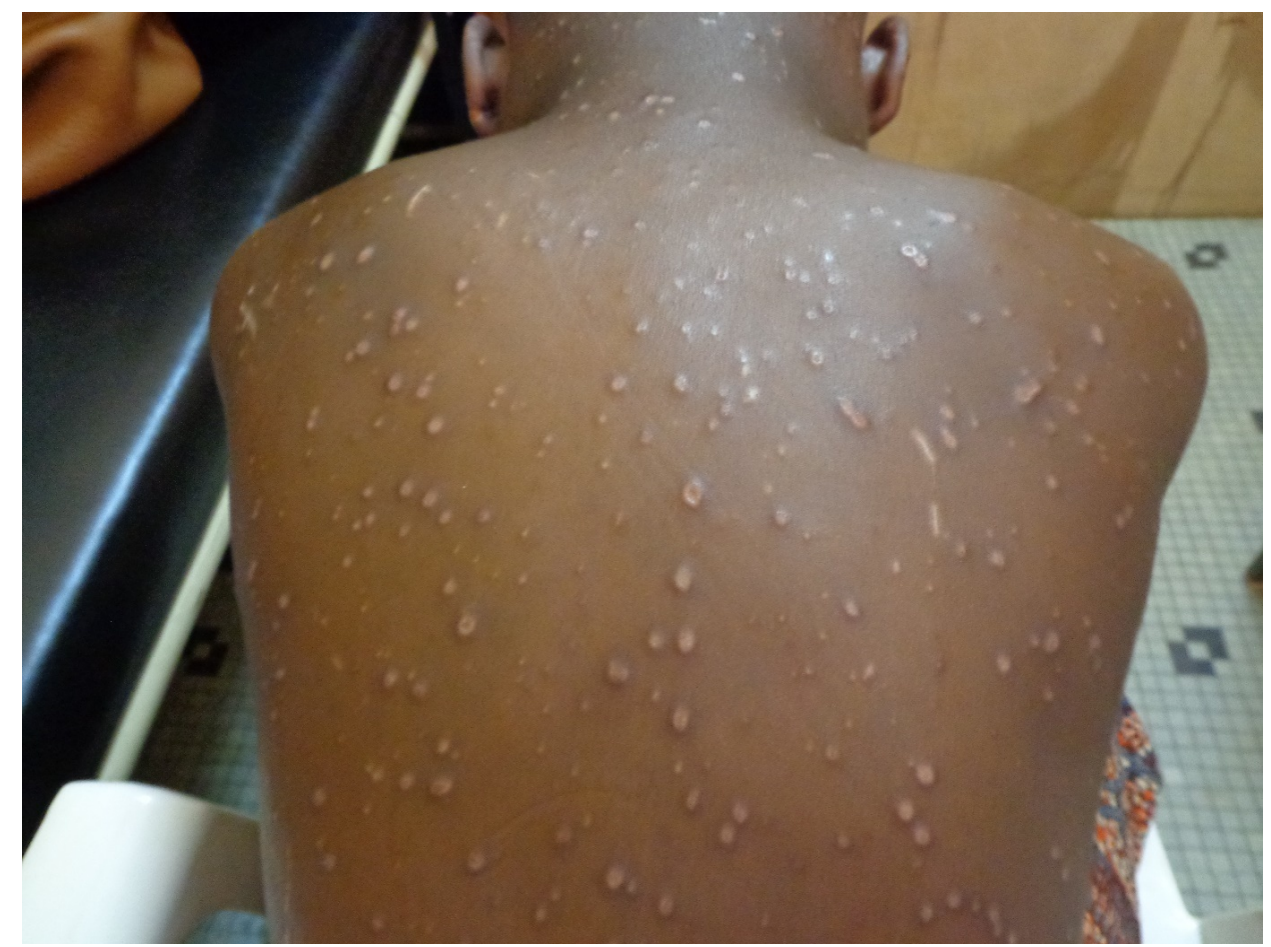

Figure 2. Dorsal location of bee stings.

surface (scalp, ears, face, neck, limbs and thorax). We noticed about 400 stitches. He had a slight fever $37.7^{\circ} \mathrm{C}$, a tachypnea at 30 cycles per minute [normal range below 30 
cycles per minute] and a tachycardia at 120 beats per minute [normal range below 100 beats per minute]. The blood pressure was $120 / 60 \mathrm{~mm} \mathrm{Hg}$ [normal range below 130/80 $\mathrm{mm} \mathrm{Hg}$. He received a paracetamol-based analgesic of $15 \mathrm{mg} / \mathrm{kg}$ dose combined with $20 \mathrm{mg}$ of nefopam every 6 hours, a vascular filling with isotonic saline serum of 20 $\mathrm{ml} / \mathrm{kg}$ dose. He received $0.2 \mathrm{mg}$ dose of adrenalin, a betamethasone-based corticosteroid $8 \mathrm{mg} /$ day and an antihistamine. We removed the stings. A local antisepsis was made with hexamidine solution and chlorhexidine and an antibiotic with amoxicillin-acid clavulanic of $80 \mathrm{mg} / \mathrm{kg}$ dose divided into three daily doses was administered. Laboratory tests revealed an hyperuremia $1.68 \mathrm{~g} / \mathrm{l}[0.10-0.40 \mathrm{~g} / \mathrm{l}]$, an elevated serum creatinine concentrations at $50 \mathrm{mg} / \mathrm{l}[4-6 \mathrm{mg} / \mathrm{l}]$, a severe anemia at $6 \mathrm{~g} / \mathrm{dl}[12-14.5 \mathrm{~g} / \mathrm{dl}]$, an hyperleukocytosis at $12,300 / \mathrm{mm}^{3}\left[4500-11000 / \mathrm{mm}^{3}\right]$ of neutrophilic $7600 / \mathrm{mm}^{3}[2000-$ $6000 / \mathrm{mm}^{3}$ ] predominant and eosinophils $861 / \mathrm{mm}^{3}\left[100-400 / \mathrm{mm}^{3}\right]$, a thrombocytopenia $78000 / \mathrm{mm}^{3}\left[150000-400000 / \mathrm{mm}^{3}\right]$, an accelerated erythrocyte sedimentation rate at $74 \mathrm{~mm}$ in the first hour [normal range below $20 \mathrm{~mm}$ ]. The blood smear revealed the presence of spherocytes and schistocytes. The liver function test was disrupted with aspartate aminotransferase 18 times to the normal and alanine aminotransferase 23 times to the normal. We noticed a slight increase of unconjugated bilirubin fraction with no impact on the total bilirubin. The Serologies of the viral hepatitis B and C were negative. The blood calcium rate was at $66 \mathrm{mg} / \mathrm{l}$ [90 - 110]. The urinary dipstick found a cross proteinuria with a proteinuria of 24 -hours at $638 \mathrm{mg}$ or $18.22 \mathrm{mg} / \mathrm{kg} / \mathrm{day}$. The rapid diagnostic test for malaria was positive; which required intravenous artesunate. The evolution had shown on the 2nd day of hospitalization the presence of oligoanuria with Coca-Cola urine. The levels of uraemia $(3.06 \mathrm{~g} / \mathrm{l})$ and creatinine $(107 \mathrm{mg} / \mathrm{l})$ continued to increase; four sessions of extra-renal purification were taken to restore a normal urine output and renal tests (urea $0.13 \mathrm{~g} / \mathrm{l}$ and creatinine $7 \mathrm{mg} / \mathrm{l}$ ). On the 17th day of hospitalization, when he was about to be discharged, he presented general convulsions with a confusing post critical syndrome but responded well to treatment after symptomatic care. He has been discharged on $24^{\text {th }}$ day and keeps a ptosis sequel left.

\section{Comments}

Bee venom is composed of enzymes and toxic biological substances such as mellitin, phospholipase A2, hyaluronidase, histamine and apamin. The mellitin, bees specific, is the main component of the venom (50\%) and is responsible for inflammatory reaction, cytolysis, intravascular hemolysis and rhabdomyolysis that can complicate and lead to kidney disease. Phospholipase A2 may result in disseminated intravascular coagulation (DIC). Hyaluronidase increases capillary permeability and facilitates the spread of toxins. The apamine is neurotoxic [1]-[5]. The attacks in urban areas as in our case are rare; it is often occurred most of times in rural areas [6]. The severity of the clinical picture of our patient is due on the one hand to the location of the stings in the head end and to the extension to the entire skin surface and on the other hand to his young age. It is illustrated by the multiplicity of the clinical signs of toxicity [4] observed after the attack: febrile reaction, hemolytic anemia, thrombocytopenia, hemoglobinuria, ren- 
al impairment. The Clinical manifestations of direct toxicity venom are often delayed by 24 to 48 hours. This involves a monitoring in intensive care with continuous monitoring of clinical and biological parameters from 50 stings in adults and a bite per kilogram of weight for the child even if the patient looks stable. But in some cases they occur immediately, making the distinction with anaphylactic reaction difficult [7]. The vascular expansion and the adrenaline are necessary to maintain an effective blood volume because the venom induced a vasopermeability despite the initial arterial hypertension reaction. The use of antihistamines and corticosteroids in high doses is recommended. Only an early care in intensive care by proper vascular filling, corticosteroids and adrenaline administration may prevent the occurrence of multiple organs dysfunction syndromes [8]. Between 250 and 500 bites, death can occur in adults but deaths have already been recorded from thirty simultaneous bites [3]. In the literature some rare cases of survival after massive bites have been described [9]. The risk of an acute renal failure is real from 100 stings because of the hemolysis induced by the venom. Kidney impairments during envenomations are due to direct toxicity of the venom on the tubules, on the prolonged hypovolemia or on the myoglobinuria second to tubulopathy and hemoglobinuria [1] [7] [10]. They usually heal without sequel but some cases that require hemodialysis as in our patient have been described [3] [6] [10] [11]; sometimes nephrotic syndrome can occur in the distance. Our patient had already proteinuria at $18 \mathrm{mg} / \mathrm{kg} / \mathrm{day}$; he will receive regular monitoring of renal function. An important liver cytolysis was found in our patient; as the serologies of hepatitis B and C viruses were negative, this cytolysis has been linked to the toxic syndrome. Neurological manifestations have been a bit reported in the literature [8]. The removal of stings must be done by a slight scratching so as to avoid pressure that would empty the venom gland. Local disinfection must be made; iodized products should be avoided. The pain requires analgesia morphine; we got a good result with paracetamol associated with nefopam. A similar case to ours has been reported in Morocco with a favorable evolution thanks to an early symptomatic care and a ptosis sequel after conjunctivitis [12]. The prognosis is correlated with plasma concentrations of venom aplasmapheresis may be useful in severe forms.

\section{Conclusion}

The massive envenomations are very serious accidents potentially mortal. Their complications mainly hemolytic anemia, renal failure and convulsion must be known and detected early because the evolution and the prognosis can be significantly improved through an early and effective symptom care.

\section{References}

[1] Munoz-Arizpe, R., Velasquez-Jones, L., Romero-Navarro, B. and Gomez-Chico, R. (1992) Acute Kidney Failure Due to Stings by Africanized Bees. Boletín Médico del Hospital Infantil de México, 49, 388-390.

[2] Betten, D.P., Richardson, W.H., Tong, T.C. and Clark, R.F. (2006) Massive Honey Bee Envenomation-Induced Rhabdomyolysis in an Adolescent. Pediatrics, 117, 231-235. 
http://dx.doi.org/10.1542/peds.2005-1075

[3] Bresolin, N.L., Carvalho, L.C., Goes, E.C., Fernandes, R. and Barrotto, A.M. (2002) Acute Renal Failure Following Massive Attack by Africanized Bee Stings. Pediatric Nephrology, 17, 625-627. http://dx.doi.org/10.1007/s00467-002-0888-0

[4] Kolecki, P. (1999) Delayed Toxic Reaction Following Massive Bee Envenomation. Annals of Emergency Medicine, 33, 114-116. http://dx.doi.org/10.1016/S0196-0644(99)70428-2

[5] Mackler, B.F. and Kreil, G. (1977) Honey Bee Venommellitin: Correlation of Non Specific Inflammatory Activities with Amino Acid Sequences. Inflammation, 2, 55-56. http://dx.doi.org/10.1007/BF00920875

[6] Gabriel, D.P., Rodrigues Jr., A.G, Barsante, R.C., dos Santos Silva, V., Caramori, J.T., Martim, L.C., Barretti, P. and Balbi, A.L. (2004) Severe Acute Renal Failure after Massive Attack of Africanized Bees. Nephrology Dialysis Transplantation, 19, 2680. http://dx.doi.org/10.1093/ndt/gfh440

[7] Odinaka, K.K., Achigbu, K., Ike, I. and Iregbu, F. (2015) Bee Sting Envenomation Resulting in Gross Haematuria in an Eight-Year-Old Nigerian Male with Sickle Cell Anaemia: A Case Report. Nigerian Medical Journal, 56, 69-70. http://dx.doi.org/10.4103/0300-1652.149175

[8] Kouamé, E.K., Brouh, Y. and Boua, N. (2004) Envenimation massive par un essaim d'abeilles chez un nourrisson. Archives de Pédiatrie, 11, 1333-1335.

http://dx.doi.org/10.1016/S0929-693X(04)00386-0

[9] Daher Ede, F., da Silva Junior, G.B., Bezema, G.P., Pontes, L.B., Martins, A.M. and Guiamaraes, J.A. (2003) Acute Renal Failure after Massive Honey Bee Stings. Revista do Instituto de Medicina Tropical de São Paulo, 45, 45-50.

[10] Daher Ede, F., Oliveira, R.A., Silva, L.S., Silva, E.M. and Morais, T.P. (2009) Acute Renal Failure Following Bee Stings: Case Reports. Revista da Sociedade Brasileira de Medicina Tropical, 42, 209-212.

[11] Bourgain, C., Pauti, M.D., Fillastre, J.P., Godin, M., François, A., Leroy, J.P., Droy, J.M. and Klotz, F. (1998) Massive Poisoning by African Bee Sting. La Presse Médicale, 27, 1099-1101.

[12] Berdai, M.A., Labib, M.A., El Balbal, M. and Harandou M. (2011) Piqures massives par un essaim d'abeilles chez un enfant. Pan African Medical Journal, 10, 16.

http://dx.doi.org/10.4314/pamj.v10i0.72225

\section{Submit or recommend next manuscript to SCIRP and we will provide best service for you:}

Accepting pre-submission inquiries through Email, Facebook, LinkedIn, Twitter, etc.

A wide selection of journals (inclusive of 9 subjects, more than 200 journals)

Providing 24-hour high-quality service

User-friendly online submission system

Fair and swift peer-review system

Efficient typesetting and proofreading procedure

Display of the result of downloads and visits, as well as the number of cited articles

Maximum dissemination of your research work

Submit your manuscript at: http://papersubmission.scirp.org/ 